\title{
Microevolution of human archaic groups of Arica, northern Chile, and its genetic contribution to populations from the Formative Period
}

\author{
Microevolución de grupos humanos arcaicos de Arica, norte de Chile, y su contribución \\ genética a las poblaciones del Período Formativo
}

\author{
HÉCTOR HUGO VARELA ${ }^{1,2}$, JOSÉ ALBERTO COCILOVO ${ }^{1,2}$, CALOGERO M. SANTORO $^{3}$ \\ $\&$ FRANCISCO ROTHHAMMER ${ }^{3 *}$
}

\author{
${ }^{1}$ Departamento de Ciencias Naturales. Facultad de Ciencias Exactas, Físico-Químicas y Naturales, \\ Universidad Nacional de Río Cuarto, 5800 Río Cuarto, Córdoba, Argentina \\ ${ }^{2}$ Consejo Nacional de Investigaciones Científicas y Técnicas (CONICET) \\ ${ }^{3}$ Universidad de Tarapacá, Centro de Investigaciones del Hombre en el Desierto (CIHDE), Arica, \& Programa de Genética \\ Humana, Instituto de Ciencias Biomédicas, Facultad de Medicina, Universidad de Chile, Chile; \\ * e-mail for correspondence: frothham@med.uchile.cl
}

\begin{abstract}
The microevolution of the archaic populations from Chile's northern coast and its morphological contribution to Formative period groups was studied. The sample comprised 181 individuals belonging to two Archaic (Morro-Uhle and Morro 1-1/6) and one Formative (Playa Miller-7 [Plm-7]) series of the coast and one sample from the Formative (Alto Ramírez) exhumed at the Azapa Valley. A total of 29 metric variables of the cranium were analyzed. Biological variability was assessed using discriminant analysis and Mahalanobis' $\mathrm{D}^{2}$ distance stadistic (MDS). Population structure was inferred using a method based on quantitative genetic theory that predicts a lineal relationship between average within-group phenotypic variance and group distance to the population centroid. The four samples studied proved to be different from a morphologic point of view. The greatest distance was observed between Plm-7 (coast Formative) and Alto Ramirez (valley Formative), the least between Morro-Uhle and Morro 1-1/6, the remaining distances presenting intermediate values. Regarding the total population, the most divergent group was Alto Ramírez and the least divergent was Morro1-1/6. A gradual biologic change was observed between Archaic (Morro Uhle and Morro 1-1/6) and coastal Formative populations (Plm-7) pointing to a morphological (genetic) contribution of Archaic fishermen to Formative population of Chile's northern coast, without excluding gene flow from other groups of the South Central Andean Area.
\end{abstract}

Key words: quantitative cranial traits, Chinchorro, late archaic, formative, northern Chile.

\section{RESUMEN}

Estudiamos la microevolución de las poblaciones arcaicas de la costa norte y sus contribuciones morfológicas al Período Formativo. La muestra comprendió 181 individuos pertenecientes a dos colecciones arcaicas de la costa (Morro-Uhle y Morro 1-1/6) y una al formativo (Alto Ramírez) exhumada en el Valle de Azapa. Un total de 29 variables métricas del cráneo fueron analizadas. La variabilidad biológica fue determinada utilizando análisis discriminante y distancias de Mahalanobis (MDS). La estructura de población se analizó utilizando un método basado en teoría genética cuantitativa que predice una relación lineal entre la varianza promedio intragrupal y su distancia hacia el centroide poblacional. Las cuatro muestras analizadas demostraron ser morfológicamente diferentes. La mayor diferencia fue observada entre Plm-7 (Formativo costero) y Alto Ramírez (Formativo valluno), la menor entre Morro-Uhle y Morro 1-1/6, teniendo las otras distancias valores intermedios. El grupo más divergente fue Alto Ramírez y el menos divergente Morro 1-1/6. Un cambio gradual morfológico se observó entre el arcaico (Morro Uhle y Morro 1-1/6) y el Formativo costero (Plm-7) indicando una contribución morfológica (genética) de los pescadores arcaicos a las poblaciones formativas en la costa del norte de Chile, sin excluir, por cierto, flujo génico de otros grupos de la región centro-sur andina.

Palabras claves: rasgos craniométricos, Chinchorro, arcaico tardío, formativo norte de Chile. 


\section{INTRODUCTION}

The intense aridity of northern Chile is interrupted by valleys that were settled by human groups in the Holocene (ca. 9,000 years BP). The Azapa Valley for example, shows a chronological sequence from the Archaic to the contact with the Spanish conquerors that is characteristic of this area, where the following cultural periods with approximate chronologies can be distinguished: Archaic (10,000-3,000 years BP); Formative (3,000-1,500 years BP); Middle or Tiwanaku (1,500-1,000 years BP); Regional Development (1,000-500 years BP) and Late or Inka (500-550 years BP).

The coast of the Azapa Valley was inhabited by groups who subsisted mainly on resources from the sea and coast. This maritime diet was complemented with terrestrial plants and land mammals. The instruments used for hunting and fishing were shell and cactus fishhooks, harpoons, darts, throwing sticks and lithic tools (Llagostera 1989, Rivera 1991, 1992, Arriaza 1995a). These communities which are associated with the Chinchorro culture, buried their dead in an extended position and practiced artificial mummification (Allison et al. 1984, Llagostera 1989, Rivera 1991, 1992, Arriaza 1995a, 1995b, Standen 1997). Although Arriaza (1995a, 1995b) proposes a chronological sequence based on mummification styles, Standen (1997) notes a coexistence among the different types of body preparation based on radiocarbon dates and the position of the bodies. The Chinchorro group has been furthermore characterized as a semisedentary maritime society, as indicated by the existence of precarious habitational structures (Núñez 1989, Rivera 1991, Arriaza 1995b). A lively controversy concerning the origin of the Chinchorro people has confronted two groups of scientists for the last decades. One group has postulated that the Chinchorro arrived at the Pacific coast as part of a migration from Amazonia (Rivera \& Rothhammer 1991) and the other that Chinchorro culture is a regional development (Arriaza 1995, Standen \& Santoro 2004). Mitochondrial DNA studies are being presently conducted by our group in an effort to settle this interesting debate.

The available archaeological evidence indicates that the coastal groups experienced around 3,500 years BP cultural changes stemming from the arrival of immigrants from the Altiplano (probably from the Titicaca area). These highland influences are evident in coastal handcrafts, crops, and burial and residential patterns. As a consequence of this contact, a new development started around 3000 BP., which gradually led to the agricultural maritime societies of the Formative Period. The Azapa and Alto Ramírez phase sites are located in the valley and on the coast (Focacci 1974, Santoro 1981, Dauelsberg 1985, Rivera 1987, Muñoz 1989). These groups buried their unmummified dead with funerary offerings in an flexed position, covered with woolen blankets. Body ornaments, turbans, trophy heads and tools for hallucinogen inhalation are frequent, as well as ceramics and metallurgy. Crops such as chili pepper, cotton, beans and squash, are also found in the tombs (Romero et al. 2004).

Although several studies have been conducted using samples from the Azapa Valley and other prehistoric groups from neighboring areas (Rothhammer et al. 1982, 1984, Guillen 1992, Cocilovo 1995, Cocilovo \& Rothhammer 1996a, 1996b, 1999, Cocilovo \& Varela 1998, Sutter 2000, Rothhammer \& Santoro 2001, Rothhammer et al. 2002, Moraga et al. 2005), up to the present the transition between Archaic and Formative has not been completely understood. In fact, whereas marked morphological differences between the coastal Archaic and the coastal Formative and absence of significant differences between this last cultural period and the Valley Formative were initially found by us, other authors arrived at contradictory results. Guillén (1992) for example using five facial measurements found a close relation between Morro 1/6 and Plm-7, Morro Uhle showing a greater distance from Morro 1/6. The low number of individuals and insufficient information provided by the scarce number of variables used in the analysis are factors that may have biased these results. A bioarchaeological study carried out by Sutter (2000) in the Moquegua (Perú) and Azapa (Chile) valleys using non-metric dental characters, assigns a direct ancestor-descendant relationship among the samples from the coastal Archaic groups and the Formative groups from the valley and the coast. However, none of the distances estimated by Sutter 
(2000) among the Arica samples is statistically significant. Recently, working with a data base obtained by a single observer (JAC), Cocilovo et al. (2001) and Varela \& Cocilovo (2002) found morphometric differences between the coastal and valley groups as well as evidence of gene flow associated to low endogamy in the valley population of the Formative period. A closer relation between the coastal (Archaic and Formative) groups could also be demonstrated, probably resulting from improvements in the experimental design including elimination of inter-observer error and removal of sex, age, artificial deformation and special environmental variation.

The objective of this paper is to evaluate the differences between Archaic (Morro Uhle, Morro 1 and Morro 1/6) and Formative (Plm-7 and Alto Ramírez) samples, in order to better understand the microevolutionary relationships among these prehistoric populations of the Azapa Valley.

\section{MATERIAL AND METHODS}

The total sample comprises 181 crania preserved in the Museum of San Miguel de Azapa (MASMA) and the National Museum of Natural History (MNHN) (Table 1) corresponding to two Archaic (Morro-Uhle and Morro 1-1/6) and one Formative coastal series from the El Laucho phase Playa Miller 7 (Plm7); and one Formative sample from the Azapa Valley belonging to Alto Ramírez phase. Using chronologies based on radiocarbon dates obtained from body tissue and associate cultural material. Morro 1 and Morro 1/6 samples can be dated between 5240-3560 years BP, whereas the Morro Uhle sample between 4,273 and 3,454 years BP.

Although there is a chronological overlap among the three Chinchorro samples (Morro Uhle, Morro 1 and Morro 1/6), it can be demonstrated that Morro Uhle is morphologically different from Morro $1\left(\mathrm{~F}_{8,170}\right.$ $=2.53, \mathrm{P}=0.0104)$, and not statistically different from Morro $1 / 6\left(\mathrm{~F}_{8,170}=0.7107, \mathrm{P}=\right.$ 0.6983). Furthermore Morro $1 / 6$ and Morro 1 have more precise and close locations. Consequently both samples were pooled. Plm$7,(530 \mathrm{BC})$ is a site located on the southern coast of Arica. Alto Ramírez include crania from sites: AZ 14, AZ 70 and AZ 115 located in the valley, approximately $12 \mathrm{~km}$ from the coast (Fig. 1). The Morro Uhle site is not indicated in the map because the exact location is not known, though it is accepted that the crania collected by Max Uhle come from the same place as those from Morro 1 and Morro 1/ 6. Sex determination ( 89 males and 92 females) was accomplished according to Acsádi \& Nemeskéri (1970) and Bass (1971) for individuals of post-reproductive age. Three age groups were considered 20-30 years $(\mathrm{n}=77)$, 30-49 years $(\mathrm{n}=85)$, and more than 49 years $(\mathrm{n}$ =19) $($ Bass 1971, Molnar 1971, Lovejoy 1985). The crania were classified according to their artificial deformation into tabular (33 erect and 18 oblique), circular (52 erect and 47 oblique) and non-deformed (31) according to Dembo \& Imbelloni (1938).

TABLE 1

Period, site, number of observations and cultural phases

Período, sitio, número de observaciones y fase cultural

\begin{tabular}{llll}
\hline Number & Period & Cultural phase & Site \\
\hline 38 & Formative & Alto Ramírez (Valley) & AZ 14, AZ 70, AZ 115 \\
47 & & El Laucho (Coast) & Playa Miller-7 \\
39 & Archaic Late & Chinchorro (Coast) & Morro 1-1/6 \\
57 & & Morro Uhle \\
\hline
\end{tabular}




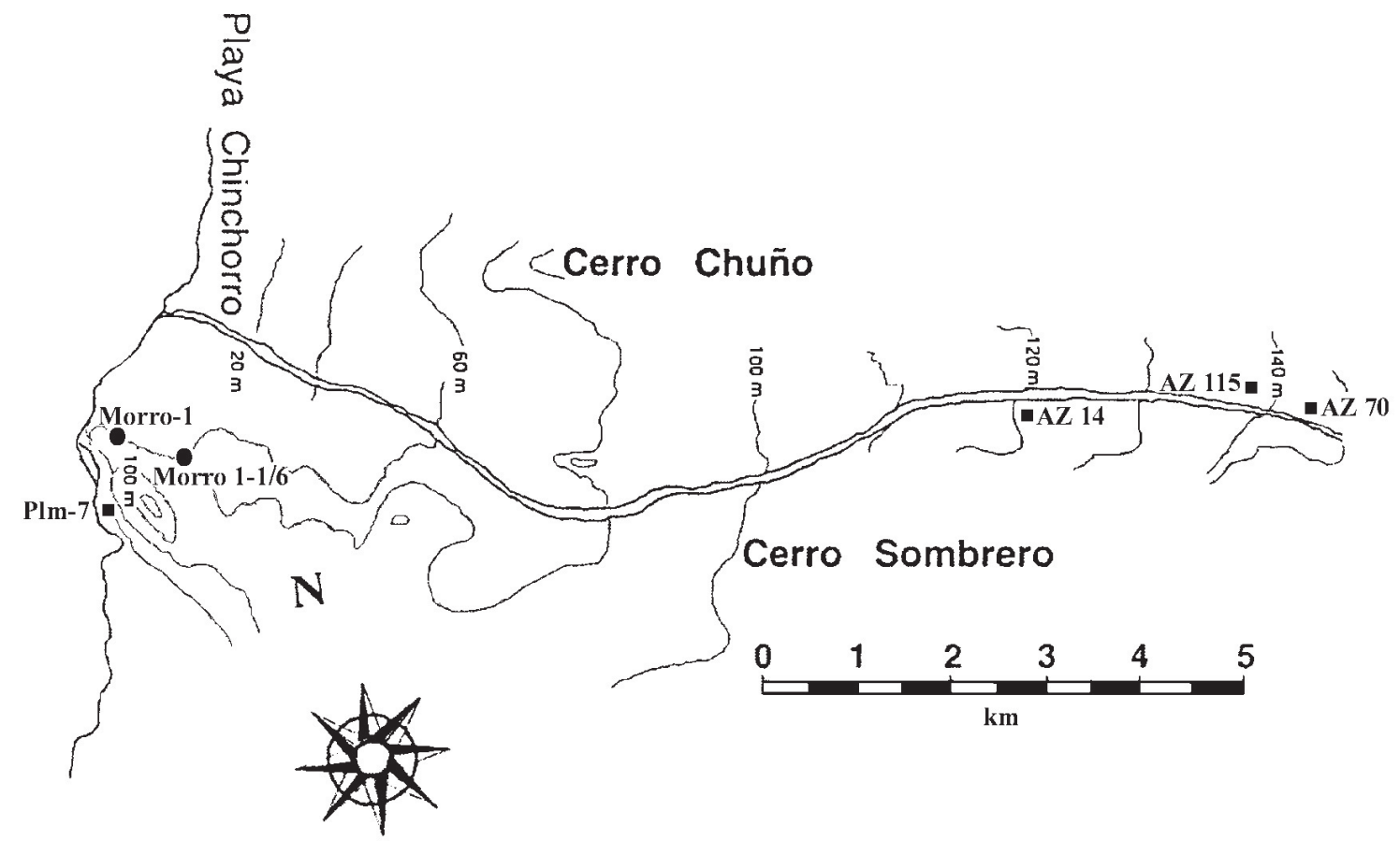

Fig. 1: Map of the Azapa Valley showing the location of the sites examined (Modified from Sutter 2000). . ircle $=$ Archaic period sites, square $=$ Formative period sites.

Mapa del Valle de Azapa mostrando la ubicación de los sitios estudiados (Modificado de Sutter 2000). Círculo = Sitios del período Arcaico, cuadrado $=$ Sitios del período Formativo.

Table 2 shows the 29 metric traits considered in this study. With the purpose of reducing the number of variables, the first eight principal components were computed and corrected eliminating variation resulting from sex, deformation and age by linear regression. Within-group and among-groups biologic variability were evaluated by means of canonical discriminant analysis and Mahalanobis' $\mathrm{D}^{2}$ distance statistic (MDS) (Rao 1952, Anderson 1984, Seber 1984). Population structure was inferred from the model for quantitative traits proposed by Relethford \& Blangero (1990), which predicts a lineal relationship between average within-group phenotypic variance and the distance from each of them to the population centroid. The model assumes selectively neutral traits, a similar mutation rate for all populations, constant migration, and a similar number of migrants between population pairs. This model can be expressed as $\mathrm{E}\left(\overline{\mathrm{V}}_{\mathrm{Pi}}\right)=\overline{\mathrm{V}}_{\mathrm{Pw}}\left(1-\mathrm{r}_{\mathrm{ii}}\right) / 1-\mathrm{Fst}$, where $\mathrm{E}\left(\overline{\mathrm{V}}_{\mathrm{Pi}}\right)$ is the expected mean phenotypic variance of the population $i, \overline{\mathrm{V}}_{\mathrm{Pw}}$ is the pooled average within-group phenotypic variance, $r_{\mathrm{ii}}$ is the genetic distance of population $i$ to the centroid and Fst is the average genetic distance to the centroid, which is estimated as the mean for the $\mathrm{r}_{\mathrm{ii}}$ for all populations (Relethford \& Blangero 1990, Relethford 1994, 1996, Relethford \& Harpending 1994, Relethford et al. 1997). We employed Relethford's software RMET 5.0 for Windows for obtaining Fst estimates (Relethford 1996). The samples used meet the criteria necessary for the application of such a model over time (Konigsberg 1990).

Values of $F_{\text {st }}$ were estimated using first an average heredability $\left(\mathrm{h}^{2}\right)$ of 0.8 for all characters. This last value was derived from the repeatability estimate (proportion of phenotypic variance explained by genetic variance plus general environmental variance), obtained for cranial quantitative traits in prehistoric populations from the north of Chile (see Varela \& Cocilovo, 1999, 2000, 2002); repeatability can be considered the upper limit of the real $\mathrm{h}^{2}$ (Falconer \& Mackay 1996). Fst was also estimated assuming an average $\mathrm{h}^{2}$ for craniometric traits of 0.55 in agreement with Relethford (1994) and Relethford \& Harpending (1994). 
TABLE 2

RESULTS AND DISCUSSION

Skull measurements used

Medidas del cráneo empleadas

\begin{tabular}{|c|c|}
\hline Measurement & Reference \\
\hline Orbito-alveolar height & Wilder (1920) \\
\hline Nasion-prosthion line & Wilder (1920) \\
\hline Nasal length & Wilder (1920) \\
\hline Cheek bone height & Bräuer (1988) \\
\hline Occipital arc & Wilder (1920) \\
\hline Maximun cranial breadth & Wilder (1920) \\
\hline Greatest frontal breadth & Wilder (1920) \\
\hline Porion-bregma height & Bass (1971) \\
\hline Basion-bregma height & Bass (1971) \\
\hline Parietal arc & Wilder (1920) \\
\hline Frontal arc & Wilder (1920) \\
\hline Palatal breadth & Wilder (1920) \\
\hline Nasal breadth & Bass (1971) \\
\hline Maxillo-alveolar breadth & Wilder (1920) \\
\hline Least frontal breadth & Wilder (1920) \\
\hline Upper facial breadth & Buikstra \& Ubelaker (1994) \\
\hline Biorbital breadth & Buikstra \& Ubelaker (1994) \\
\hline Orbital breadth & Buikstra \& Ubelaker (1994) \\
\hline Bizygomatic breadth & Bass (1971) \\
\hline Maximum cranial length & Wilder (1920) \\
\hline Maxillo-alveolar length & Wilder (1920) \\
\hline Palatal length & Wilder (1920) \\
\hline Basion-prosthion length & Wilder (1920) \\
\hline Foramen magnum breadth & Buikstra \& Ubelaker (1994) \\
\hline Foramen magnum length & Buikstra \& Ubelaker (1994) \\
\hline Orbital height & Wilder (1920) \\
\hline Horizontal circumference & Wilder (1920) \\
\hline $\begin{array}{l}\text { Basion-nasion length/cranial } \\
\text { base length }\end{array}$ & Wilder (1920) \\
\hline Bimaxillary breadth & Brothwell (1981) \\
\hline
\end{tabular}

With the exception of the distance between Morro Uhle y Morro 1-1/6, MDS (Table 3) are statistically significant (Bonferroni corrected $\mathrm{P}$ $<0.0017)$, the highest value (3.024) occurs between Plm-7 and Alto Ramírez and the smallest (0.972) between Morro Uhle and Morro 1-1/6. MDS values indicate that Plm-7 is closer to Morro Uhle and Morro 1-1/6 than to Alto Ramírez, thus indicating a greater relationship between the Archaic coastal samples and the ones from the coastal Formative than to the sample from the Azapa Valley from the same period.

Table 4 shows the results of canonical discriminant analysis, where the first two components account for $88 \%$ of the total among-group variability, while the third accounts for the remaining $12 \%$. Inspection of Table 5 and Fig. 2 indicates that the first coordinate (accounting for $49 \%$ of the variation) separates Alto Ramírez (valley Formative) from Plm-7 (coast Formative), the archaic coastal groups (Morro 1-1/6 and Morro Uhle) being closer to Plm-7 than to Alto Ramírez. The second coordinate (accounting for $39 \%$ of the variation) distinguishes between the Archaic (Morro Uhle and Morro 1-1/6) and the Formative (Alto Ramírez and Plm-7).

It is necessary to consider that the Alto Ramírez sample from the interior of the valley is heterogenous from the chronologic point of view, spanning a range of almost 1,500 years, having this fact obviously some influence on the estimated distance between samples.

TABLE 3

Squared distances between groups ${ }^{1}$

Distancias cuadradas entre grupos ${ }^{1}$

\begin{tabular}{lrrrr}
\hline Group & \multicolumn{3}{c}{ Mahalanobis' D ${ }^{2}$} \\
\cline { 2 - 5 } & Morro Uhle & Morro 1-1/6 & Plm-7 & Alto Ramírez \\
\hline Morro Uhle & - & 0.972 & 2.024 & 2.453 \\
Morro 1-1/6 & $-.640(0.009)$ & -- & 1.266 & 1.911 \\
Plm7 & $6.135(0.000)$ & $3.162(0.002)$ & --1.024 \\
Alto Ramírez & $6.560(0.000)$ & $4.301(0.000)$ & $7.445(0.000)$ & -- \\
\hline
\end{tabular}

${ }^{1}$ Upper trimat corresponds to $\mathrm{D}^{2}$ values, lower trimat to $\mathrm{F}$ and $\mathrm{p}$ (in parentheses) values 
TABLE 4

Canonical discriminant analysis

Análisis discriminante canónico

\begin{tabular}{lccc}
\hline & Component I & Component II & Component III \\
\hline Eigenvalue & 0.3536 & 0.2762 & 0.0859 \\
Relative percentage & 49.40 & 38.60 & 12.00 \\
Wilks' lambda & 0.5331 & 0.7216 & 0.9209 \\
Chi-square & 109.45 & 56.78 & 14.34 \\
P-value & 0.0000 & 0.0000 & 0.0261 \\
\hline
\end{tabular}

TABLE 5

Means of canonical components

Medias de las componentes canónicas

\begin{tabular}{lccc}
\hline Group & Component I & Component II & Component III \\
\hline Morro Uhle & 0.0692 & 0.6981 & -0.1732 \\
Morro 1-1/6 & 0.0879 & 0.0458 & 0.5507 \\
Plm-7 & 0.6773 & -0.5703 & -0.1640 \\
Alto Ramírez & -1.0317 & -0.3888 & -0.1025 \\
\hline
\end{tabular}

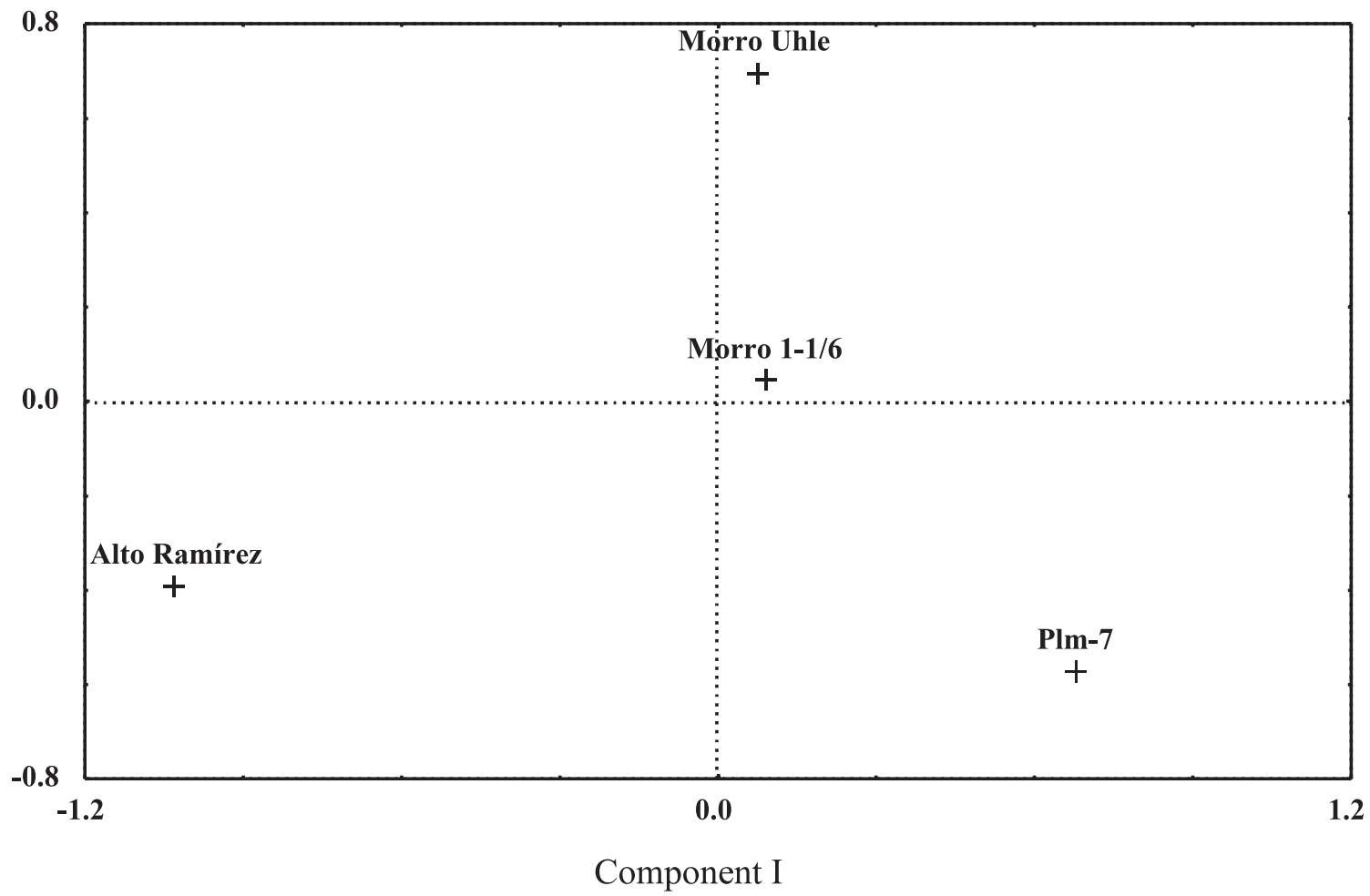

Fig. 2: Group distribution based on first two canonical variables.

Distribución de los grupos basada en las dos primeras variables canónicas. 
The closest association between Archaic samples (Morro Uhle and Morro 1-1/6) and Plm-7 (Table 3 and 5, Fig. 2) is consistent with the archaeological evidence, as they signal the existence of a clear kinship between archaic groups and the coastal Formative population.

The Relethford \& Blangero's (1990) model establishes a balance between gene flow and genetic drift. Deviations from the model are accounted for by reduced effective population size or by differences in gene flow rates, in such a way that greater-than-expected variances indicate higher gene flow rates. Since we were assuming effective sizes being equal for all subpopulations, deviations from the model are mainly explained by differences in gene flow rate. The results of the application of this method can be observed in Table 6, which shows that those groups with greater distance from the centroid $\left(\mathrm{r}_{\mathrm{ii}}\right)$ are Alto Ramírez, Plm-7 and Morro Uhle, while Morro 1-1/6 is very close to the population mean. Since $r_{i i}$ values are subject to sample bias, they can be corrected by subtracting the $1 / 2 n_{i}$ value, where $\mathrm{n}_{\mathrm{i}}$ is the sample size of group $i$ (Relethford et al. 1997). Table 6 shows biased and unbiased distances to the centroid. The estimated unbiased value for within-group average kinship $\left(\mathrm{F}_{\mathrm{st}}\right)$ was 0.04 , meaning that $4 \%$ of the total variation is explained by the existing among-group variation whereas $96 \%$ is attributable to within-group variation. When a $\mathrm{h}^{2}$ value of 0.55 is used, $\mathrm{F}_{\text {st }}$ increases to $0.06 \pm$ 0.0091 . The genetic divergence calculated is within the range of estimations achieved for aboriginal populations from the southern central Andes area (Rothhammer et al. 1990,
Cocilovo \& Varela 1998, Varela \& Cocilovo 2000, 2002).

Table 6 also shows that Archaic groups present a negative residual variance (observed variance minus expected variance), which might indicate greater isolation. On the other hand, Alto Ramírez shows an excess of withingroup variance suggesting greater long range migration, whereas Plm-7 shows a residual variance close to zero indicating balance between genetic drift and gene flow. These results are consistent with the archaeological interpretation that establishes that approximately 4,000 BP, hunter-gathererfishermen populations from the Archaic of northern Chile experienced a series of cultural changes stemming from Altiplano influences which, around 3,000 BP, led to the agricultural maritime societies of the Formative Period (Muñoz 1989, Rivera 1991). Santoro (1981, 2000) has suggested that the human groups established on the coast (El Laucho and Faldas del Morro phases) corresponded to maritime societies that started to practice, farming incorporating technologies that had originated in the Azapa valley close to the coast. Groups like San Miguel de Azapa or Alto Ramírez, located in the valley away from the coast, embodied instead a new cultural tradition integrating coastal populations that had adopted this inland territory as their home land and groups from the Highlands and the northern neighboring valleys, which maintained relationships with the Titicaca basin. Consequently, these inland populations became connected by a network of exchanges through which new people, as well as imported items

TABLE 6

Distance to the centroid and within-group phenotypic variance ${ }^{1}$

Distancia al centroide y varianza fenotípica dentro de grupo ${ }^{1}$

\begin{tabular}{lcccccc}
\hline Group & $\mathrm{r}_{\mathrm{ii} \text { (biased) }}$ & $\mathrm{r}_{\mathrm{ii} \text { (unbiased) }}$ & $\mathrm{SE}$ & $\mathrm{V}_{\mathrm{o}}$ & $\mathrm{V}_{\mathrm{e}}$ & $\mathrm{V}_{\mathrm{r}}$ \\
\hline Morro Uhle & 0.0448 & 0.0361 & 0.0137 & 0.821 & 0.963 & -0.143 \\
Morro 1-1/6 & 0.0223 & 0.0094 & 0.0116 & 0.862 & 0.990 & -0.128 \\
Plm-7 & 0.0600 & 0.0493 & 0.0174 & 0.970 & 0.950 & 0.019 \\
Alto Ramírez & 0.0789 & 0.0658 & 0.0222 & 1.185 & 0.934 & 0.252 \\
F $_{\text {st }}$ & 0.0515 & 0.0402 & 0.0079 & & &
\end{tabular}

${ }^{1} \mathrm{r}_{\mathrm{ii}}$ : distance to the centroid, se: standard error of $\mathrm{r}_{\mathrm{ii}}$, Vo: observed variance, Ve: expected variance; Vr: residual variance. Fst: average distance to the centroid 
such as highland pottery, textiles and metal objects were subsequently incorporated. Examples of this new cultural tradition are the Azapa and Alto Ramírez phases. This more elaborate model replaces the traditional one which interpreted the acquisition of imported items only as evidence of the arrival of colonists from the Titicaca basin.

\section{ACKNOWLEDGMENTS}

Research supported by Fondo Nacional de Investigación Científica y Tecnológica (1050595), Chile, Consejo Nacional de Investigación Científica y Tecnológica (PIP 0603/98) Argentina, Fondo para la Investigación Científica y Técnicas (PICT 0403790/98) and Universidad Nacional de Río Cuarto 1999-2000, Argentina.

\section{LITERATURE CITED}

ACSÁDI G \& J NEMESKÉRI (1970) History of human life span and mortality. Akadémiai Kiadó, Budapest, Hungary. 346 pp.

ANDERSON TW (1984) An Introduction to Multivariate Statistical Analysis. John Wiley \& Sons, Inc., New York, USA, $675 \mathrm{pp}$.

ALLISON M, FOCACCI G, ARRIAZA B, STANDEN V, RIVERA M \& J LOWENSTEIN (1984) Chinchorro. Momias de preparación complicada: métodos de momificación. Chungará (Chile) 13:155-174.

ARRIAZA BT (1995a) Chinchorro bioarchaeology: chronology and mummy seration. Latin American Antiquity 6: 35-55.

ARRIAZA BT (1995b) Beyond death: the Chinchorro mummies of ancient Chile. Smithsonian Institution Press, Washington USA, $176 \mathrm{pp}$.

BASS WM (1971) Human osteology: a laboratory and field manual of the human skeleton. University of Missouri Press, Springfield, Missouri, USA, 271pp.

BRÄUER G (1988) Osteometrie. In: Knussmann R (ed) Anthropologie. Band I/1: 160-232. Fischer, Stuttgart, Germany.

BROTHWELL DR (1981) Digging up bones. Cornell University Press, Ithaca, New York, USA. 196 pp.

BUIKSTRA J \& D UBELAKER (1994). Standards for data collection from human skeletal remains. Arkansas Archeological Survey, Fayetteville, Arkansas, USA. 206 pp.

COCILOVO JA (1995) La población prehistórica de Pisagua. Continuidad y cambio biocultural en el norte de Chile. Tesis para optar al título de Doctor en Ciencias Biológicas. Facultad de Ciencias Exactas, Físicas y Naturales. Universidad Nacional de Córdoba. Argentina.

COCILOVO JA \& F ROTHHAMMER (1996a) El Valle de Azapa en el norte de Chile. Análisis de un modelo biocronológico para establecer la estructura de la población. Revista Argentina de Antropología Biológica 1: 232-245.
COCILOVO JA \& F ROTHHAMMER (1996b) Methodological approaches for the solution of ethnohistorical problems: bioassay of kinship in prehistoric populations of Arica. Chile. Homo (Germany) 47: 177-190.

COCILOVO JA \& F ROTHHAMMER (1999) Microevolución morfológica y extinción del parentesco en asentamientos humanos prehistóricos del Valle de Azapa, Chile. Revista Chilena de Historia Natural 72: 213-218.

COCILOVO JA \& HH VARELA (1998) Variación morfológica, estructura canónica y bioensayo de parentesco en poblaciones prehistóricas del norte de Chile. Chungará (Chile) 30: 75-85.

COCILOVO JA, HH VARELA, O ESPOUEYS \& V STANDEN (2001) El Proceso microevolutivo de la población nativa antigua de Arica. Chungará (Chile) 33: 13-20.

DAUELSBERG P (1985) Faldas del Morro: fase cultural agroalfarera temprana. Chungará (Chile) 14: 7-44.

DEMBO A \& J IMBELLONI (1938) Deformaciones intencionales del cuerpo humano de carácter étnico. J. Anesi, Buenos Aires, Argentina, 384 pp.

FALCONER DS \& TFC MACKAY (1996) Introduction to quantitative genetics. Longman Group Ltd., Essex, United Kingdom. 646 pp.

FOCACCI G (1974) Excavaciones en el cementerio Playa Miller 7. Arica. Chungará (Chile) 3: 23-74.

GUILLÉN SE (1992) The Chinchorro culture: mummies and crania in the reconstruction of preceramic coastal adaptation in the South Central Andes. Ph.D. Dissertation, University of Michigan, Michigan, USA. 204 pp.

KONIGSBERG LW (1990) Analysis of prehistoric biological variation under a model of isolation by geographic and temporal distance. Human Biology 62: 49-70.

LOVEJOY CO (1985) Dental wear in the Libben population: its functional pattern and role in the determination of adult skeletal age and death. American Journal of Physical Anthropology 68: 4756.

LLAGOSTERA A (1989) Caza y pesca marítima (9.000 a 1.000 a. C.). In: Hidalgo J, V Schiappacasse, H Niemeyer, C Aldunate \& I Solimano (eds) Culturas de Chile. Prehistoria. Desde sus orígenes hasta los albores de la conquista. Santiago: 57-79. Editorial Andrés Bello, Santiago, Chile.

MOLNAR S (1971) Human tooth wear, tooth function and cultural variability. American Journal of Physical Anthropology 34: 175-190.

MORAGA M, C SANTORO, V STANDEN, P CARVALLO \& F ROTHHAMMER (2005) Microevolution in prehistoric Andean populations: chronologic mtDNA variation in the desert valleys of northern Chile. American Journal of Physical Anthropology 127: 170-181.

MUÑOZ I (1989) El período Formativo en el norte Grande. In: Hidalgo J, V Schiappacasse, H Niemeyer, C Aldunate \& I Solimano (eds) Culturas de Chile. Prehistoria. Desde sus orígenes hasta los albores de la conquista. Santiago: 107-128. Editorial Andrés Bello, Santiago, Chile.

NÚÑEZ L (1989) Hacia la producción de alimentos y la vida sedentaria (5.000 a. C a 900 d. C.). In: Hidalgo J, V Schiappacasse, H Niemeyer, C Aldunate \& I Solimano (eds) Culturas de Chile. Prehistoria. Desde sus orígenes hasta los albores de la conquista. Santiago: 81-105. Editorial Andrés Bello, Santiago, Chile. 
RAO C (1952) Advanced statistical methods in biometrics research. John Wiley \& Sons, New York, New York, USA, 390pp.

RELETHFORD JH (1994) Craniometric variation among modern human populations. American Journal of Physical Anthropology 95: 53-62.

RELETHFORD JH (1996) Genetic drift can obscure population history: problem and solution. Human Biology 68: 29-44.

RELETHFORD JH \& J BLANGERO (1990) Detection of differential gene flow patterns of quantitative variation. Human Biology 62: 5-25.

RELETHFORD JH \& HC HARPENDING (1994) Craniometric variation, genetic theory, and modern human origins. American Journal of Physical Anthropology 95: 249-270.

RELETHFORD JH, MH CRAWFORD \& J BLANGERO (1997) Genetic drift and gene flow in post-famine Ireland. Human Biology 69: 443-465.

RIVERA M (1987) Tres fechados radiométricos de pampa de Alto Ramírez, norte de Chile. Chungará (Chile) 18:7-13

RIVERA M (1991) The prehistory of northern Chile: a synthesis. Journal of World Prehistory 5: 1-47.

RIVERA M (1992) Antiguas manifestaciones de momificación humana en América: la tradición Chinchorro del norte de Chile. Beiträge Zur Allgemeinen Und Vergleichenden Archäologies 12: 337-359.

RIVERA M \& ROTHHAMMER F (1991) The Chinchorro people of northern Chile 5000 BC-500 BC: a review of their culture and relationships. Journal of Human Evolution 3: 243-255.

ROMERO Á, CM SANTORO, D VALENZUELA, J CHACAMA, E ROSELLO \& L PIACENZA (2003) Túmulos, ideología y paisaje de la fase Alto Ramírez del Valle de Azapa, Chungará. Revista de Antropología de Chile 235-247.

ROTHHAMMER F, JA COCILOVO, S QUEVEDO \& E LLOP (1982) Microevolution in prehistoric Andean populations: I. Chronologic craniometric variation. American Journal of Physical Anthropology 58: 391-396.

ROTHHAMMER F, S QUEVEDO, JA COCILOVO \& E LLOP (1984) Microevolution in prehistoric Andean population: chronologic nonmetrical cranial variation in northern Chile. American Journal of Physical Anthropology 65: 157-162.

ROTHHAMMER F, CHAKRABORTY R \& RE FERRELL (1990) Intratribal genetic differentiation as assessed through electrophoresis. In: Schull WJ \& F

Associate Editor: Sylvain Faugeron

Received May 5, 2005; accepted December 6, 2005
Rothhammer (eds) The Aymara: strategies in human adaptation to a rigorous environment: 193201. Dordrecht Kluwer Academic Publishers, Dordecht, The Netherlands.

ROTHHAMMER F \& CM SANTORO (2001) El desarrollo cultural en el Valle de Azapa. Extremo norte de Chile y su vinculación con los desplazamientos poblacionales altiplánicos. Latin American Antiquity 12: 59-66.

ROTHHAMMER F, SANTORO CM \& M MORAGA (2002) Craniofacial chronological microdifferentiation of human prehistoric populations of the Azapa Valley, northern Chile. Revista Chilena de Historia Natural 75: 259-264.

SANTORO C (1981) Formativo temprano en el extremo norte de Chile. Chungará (Chile) 8: 33-62.

SANTORO C (2000) Formativo en la región de valles occidentales del área centro sur andina. En: P Lederberger (ed) Formativo sudamericano, una revaluación: 243-254. Editorial Abya-Yala, Quito, Ecuador

SEBER GAF (1984) Multivariate observation. John Wiley \& Sons, New York, New York, USA. 685 pp.

STANDEN VG (1997) Temprana complejidad funeraria de la cultura Chinchorro (norte de Chile). Latin American Antiquity 8: 134-156.

STANDEN VG \& C SANTORO (2004) Patrón funerario arcaico temprano del sitio Acha-3 y su relación con chinchorro: cazadores pescadores y recolectores de la costa norte de Chile. Latin American Antiquity 15: 89-109.

SUTTER RC (2000) Prehistoric genetic and culture change: a bioarchaeological search for pre-Inka Altiplano colonies in the coastal valleys of Moquegua, Perú, and Azapa, Chile. Latin American Antiquity 11: 43-70.

VARELA HH \& JA COCILOVO (1999) Evaluation of the environmental component of the phenotypic variance in prehistoric population. Homo (Germany) 50: 46-53.

VARELA HH \& JA COCILOVO (2000) Structure of the prehistoric population of San Pedro de Atacama Current Anthropology 41: 125-131.

VARELA HH \& JA COCILOVO (2002) Genetic drift and gene flow in to prehistoric population of the Azapa Valley and Coast, Chile. American Journal of Physical Anthropology 118: 259-267.

WILDER H (1920) Laboratory mannual of anthropometry. P. Blakiston's Son \& Company, Philadelphia, Pennsylvania, USA. 193 pp. 